\title{
Implementasi Steganografi Menggunakan Algoritma Diversity Pada Citra Digital
}

\author{
Roji Ramadhani ${ }^{1 *}$, Dodi Siregar ${ }^{1}$, Yunita Sari Siregar ${ }^{1}$ \\ Address : Program Studi Teknik Informatika, Universitas Harapan Medan, Medan, Indonesia \\ Email : Rojirama12345@gmail.com \\ Correspondence *
}

\begin{abstract}
Abstract- Providing security and confidentiality to information is very important when exchanging information though a communication network. It is intended that the information sent by the sender can be fully accepted by the recipient without interference from parties who are not interested in the information. Steganography techniques can be used to secure secret massages. Steganography is a method for hiding information on a media. Can be in the form of image, sound or video media. The most important aspect of steganography is the level security in hiding information, which refers to how much the third party is unable to detect hidden information. The goal is to avoid suspicion. Steganography commonly used is the hiding of text information on image media. The method used is Diversity. From the results of the trial, it is known that with Diversity insertion and extraction of massages can be done well.
\end{abstract}

Keywords- Steganography, Diversity, Text.

\begin{abstract}
Abstrak
Memberikan keamanan dan kerahasiaan pada informasi sangat penting ketika bertukar informasi melalui jaringan komunikasi. Hal ini dimaksudkan bahwa informasi yang dikirim oleh pengirim dapat diterima oleh penerima tanpa campur tangan dari pihak yang tidak berkepentingan terhadap informasi tersebut. Teknik steganografi dapat digunakan untuk mengamankan pesan rahasia. Steganografi adalah metode untuk menyembunyikan informasi pada sebuah media, bisa berupa media gambar, suara ataupun video. Aspek terpenting pada steganografi adalah tingkat keamanan penyembunyian informasinya, yang megacu pada seberapa besar ketidakmampuan pihak ketiga dalam mendeteksi keberadaan informasi yang tersembunyi. Tujuannya untuk menghindari kecurigaan. Steganografi yang umumnya digunakan adalah penyembunyian informasi teks pada media gambar. Metode yang dipakai adalah Diversity. Dari hasil uji coba, diketahui bahwa dengan Diversity penyisipan dan ekstraksi pesan dapat dilakukan dengan baik.
\end{abstract}

Kata kunci- Steganografi, Diversity, Teks.

1. Pendahuluan

Perkembangan teknologi digital serta internet saat ini telah memberi kemudahan untuk melakukan akses serta mendistribusikan berbagai informasi dalam format digital. Beberapa faktor yang membuat data digital (suara, citra, video dan teks) banyak digunakan antara lain dikarenakan kemudahan dalam proses duplikasi dan hasil dari duplikasi akan tetap sama dengan aslinya, juga dikarenakan biaya yang murah dalam proses duplikasi dan penyimpanan, serta 
mudah disimpan dan kemudian untuk diolah atau diproses lebih lanjut.

Steganografi merupakan salah satu metode yang dapat digunakan untuk mengamankan pesan rahasia pada media lain seperti (citra, audio, video maupun teks). Ada beberapa metode yang digunakan dalam steganografi antara lain metode least significant bit end of file. Kualitas citra pada metode least significant bit dapat diukur dengan melakukan perhitungan nilai Mean Square Error (MSE) dan Peak Signal to Noise Ratio (PSNR), sedangkan kualitas citra berdasarkan metode and of file tidak dapat dihitung dengan perhitungan MSE dan PSNR karena kualitas citra awal dan citra setelah disisipkan pesan tidak mengalami perubahan[1].

Steganografi yang merupakan kombinasi dari tiga warna dasar Red, Green, Blue (RGB). Sedangkan satu pixel citra warna 24 bit diwakili oleh tiga byte, dimana masing-masing byte merepresentasikan warna Red, Green dan Blue. Penyisipan pesan ke dalam cover image dinamakan encoding, sedangkan ekstraksi pesan dari stego image dinamakan decoding. Kedua proses memerlukan kunci rahasia (stego key), agar hanya pihak yang mempunyai kunci rahasia saja yang dapat melakukan penyisipan dan ekstraksi pesan. Proses encoding dan decoding[2].

Perubahan yang terjadi pada citra stegano hanyalah besar data sebelum dan sesudah proses steganografi, namun tidak merubah bentuk dari citra dalam skala yang besar[3].

\section{Metode Penelitian}

\subsection{Citra}

Citra merupakan istilah lain untuk gambar sebagai salah satu komponen multimedia yang memegang peranan yang sangat penting sebagai bentuk informasi visual. Citra mempunyai karakteristik yang tidak dimiliki oleh data teks, yaitu citra kaya dengan informasi. [4].

\section{Steganografi}

Steganografi adalah ilmu seni menulis atau menyembunyikan pesan ke dalam sebuah media sehingga keberadaan pesan tidak dapat diketahui atau tidak disadari oleh indera manusia. Teknik steganografi berfungsi menyembunyikan pesan rahasia di dalam media digital sehingga keberadaan data rahasia tersebut tidak diketahui oleh orang lain[6].

\subsection{Teknik Penyembunyian Data}

Penyembunyian data dilakukan dengan mengganti bit-bit data di dalam segmen citra dengan bit-bit data rahasia. Salah satu metode penyembunyian data yang sederhana adalah $L S B$ Modification. Perhatikan contoh penyembunyian data yang sederhana untuk susunan pada sebuah byte, sebagai berikut:

$$
\begin{aligned}
& \underline{1} 101001 \underline{0} \\
& \downarrow \quad \downarrow \quad \mathrm{MSB}=\text { Most } \\
& \text { Significant Bit. } \\
& \text { MSB LSB } \\
& \text { LSB = Least Significant Bit. }
\end{aligned}
$$

Bit yang cocok untuk diganti adalah bit $L S B$, sebab perubahan tersebut hanya mengubah nilai byte satu lebih tinggi atau satu lebih rendah dari nilai sebelumnya. Misalkan byte tersebut menyatakan warna keabuan tertentu, maka perubahan satu bit LSB tidak mengubah warna keabuan tersebut secara berarti. Secara kasat mata manusia tidak dapat membedakan perubahan yang kecil di dalam perubahan warna yang terseleksi pada citra. Misalkan segmen data citra sebelum perubahan, seperti contoh berikut:

$00110011 \quad 10100010 \quad 11100$ $010 \quad 01101111$

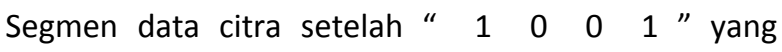
disembunyikan :

$$
\downarrow \quad \downarrow \quad \downarrow \quad \downarrow
$$

$0011001 \underline{1} 1010001 \underline{0} \quad 1110001 \underline{0} 0110111 \underline{1}$ Untuk memperkuat teknik penyembunyian data, bitbit data rahasia tidak digunakan mengganti byte-byte yang berurutan, namun dipilih susunan byte secara acak. Misalnya jika terdapat 50 byte dan 6 bit data yang akan disembunyikan, maka maka byte yang diganti bit $\angle S B$-nya dipilih secara acak, misalkan byte nomor 36, 5, 21, 10, 18, 49. Bilangan acak dibangkitkan dengan pseudo-random-numbergenerator (PRNG) kriptografi.PRNG kriptografi sebenarnya adalah algoritma kriptografi yang digunakan untuk enkripsi.PRNG dibangun dengan algoritma DES (DataEncryption Standard), algoritma hash MD5, dan mode kriptografi CFB (ChiperFeedback Mode). Tujuan enkripsi adalah menghasilkan 
sekumpulan bilangan acak yang sama untuk setiap kunci enkripsi yang sama. Bilangan acak dihasilkan dengan memilih bit-bit dari sebuah blok data hasil enkripsi. Teknik penyembunyian data untuk citra 8-bit berbeda dengan citra 24-bit. Citra bitmap terdiri atas bagian header, palet $R G B$, dan data bitmap. Pada citra 8-bit, setiap elemen data bitmap menyatakan indeks dari peta warnanya di palet $R G B[3]$. Perhatikan elemen data bitmap menyatakan indeks dari peta warnanya di palet $R G B$, seperti contoh berikut: Format citra 8-bit (256 warna):

$\begin{array}{lccl}\text { < header> } & & \\ \text { < palet } & R G B> & & \\ & R & G & B \\ 1 & 20 & 45 & 24 \\ 2 & 14 & 13 & 16 \\ 3 & 12 & 17 & 15 \\ \ldots & & & \\ 256 & 46 & 78 & 25\end{array}$

$<$ data bitmap >

\section{$2211135 \ldots$}

Pada citra 24-bit, tidak terdapat palet $R G B$, karena nilai $R G B$ langsung diuraikan dalam data bitmap.Setiap elemen data bitmap panjangnya 3 byte, masing-masing byte menyatakan komponen $R, G$, dan $B$. Perhatikan seperti contoh berikut:

Format citra 24-bit (16 juta warna):

$<$ header >

$<$ data bitmap >

$2211135 \ldots$

Pada contoh format citra 24-bit di atas, pixel pertama mempunyai $R=2, G=2, B=1$.

\section{Analisis Permasalahan}

Masalah dari penelitian ini adalah pembuatan sistem steganografi pada pesan teks pada citra digital menggunakan metode diversity. Metode diversity merupakan metode yang digunakan untuk mensubstitusikan bit-bit dari pesan teks dengan hasil transformasi bit piksel dari citra penampung. Steganografi pada citra digital menggunakan metode diversity pada citra digital untuk mencari hasil transformasi. Penerapan metode tersebut pada steganografi menghasilkan proses steganografi yang memiliki daya tampung yang lebih besar dengan berupaya menjaga kualitas dari citra penampung.

\subsection{Analisis Kebutuhan Sistem}

Analisis kebutuhan sistem meliputi analisis kebutuhan fungsional dan analisis kebutuhan nonfungsional sistem. Kebutuhan fungsional sistem adalah kebutuhan yang berisi proses-proses atau layanan apa saja yang nantinya harus disediakan oleh sistem, sedangkan kebutuhan non-fungsional sistem adalah kebutuhan yang menitik beratkan pada properti prilaku yang dimiliki oleh sistem. Adapun kebutuhan fungsional dan non-fungsional sistem yang harus dimiliki oleh sistem steganografi pada citra digital menggunakan metode diversity adalah,sebagai berikut

1. Analisi kebutuhan fungsional sistem :

a. Sistem dapat melakukan ekstraksi piksel piksel dari citra penampung.

b. Sistem dapat membentuk matriks - matriks transformasi dari tiap piksel yang digunakan pada proses substitusi.

c. Sistem dapat mencari matriks transformasi yang memiliki nilai antara RSME pada saat proses substitusi dengan bit pesan.

d. Sistem dapat melakukan penyisipan dan ekstraksi kembali.

2. Analisis Kebutuhan Non-Fungsional Sistem :

a. Sistem memiliki proses yang akurat.

Tampilan antarmuka sistem menarik dan dapat dimengerti oleh pengguna sistem.

\subsection{Pemodelan}

Penelitian ini menggunakan UML sebagai bahasa pemodelan untuk mendesain dan merancang sistem steganografi penyembunyian pesan teks pada citra digital menggunakan metode algoritma diversity. Model UML yang akan digunakan adalah use case dan activity diagram.

\section{3 pemodelan Menggunakan Use Case Diagram}

Untuk mengetahui aktor dan use case yang akan digunakan, maka dilakukan identifikasi aktor dan identifikasi use case. Setelah mendapatkan aktor dan use case, maka use case diagram dapat digambarkan. Aktor yang berinteraksi dengan system ini adalah user yang terdiri atas satu jenis yaitu : user. Sistem dapat melakukan penyisipan dan ekstraksi seperti pada gambar 1 . 


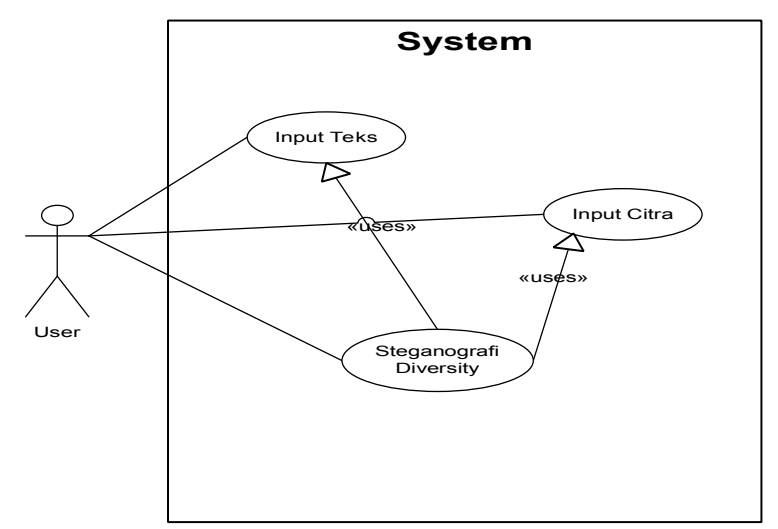

Gambar 1 Use Case Diagram yang akan dikembangkan.

Use Case Diagram seperti yang terlihat pada gambar 1 , dapat dilihat bahwa pengguna berinteraksi dengan aplikasi melalui tiga use case yang berbeda yaitu use case Input Teks Rahasia, use case Input Citra, use case Steganografi Diversity. Adapun penjelasan dari tiap use case adalah sebagai berikut:

1. Use Case Input Teks Rahasia, use case ini mendeskripsikan bagaimana pengguna berinteraksi dengan melakukan input teks rahasia yang akan disisipkan kedalam citra penampung. Pengguna memilih menu yang tersedia untuk membuka file teks atau dengan mengisi langsung teks rahasia pada kolom yang disediakan.

2. Use Case Input Citra, use case ini mendeskripsikan bagaimana pengguna berinteraksi dengan melakukan input file citra digital yang akan disisipkan dengan pesan rahasia. Pengguna memilih menu yang tersedia untuk membuka file citra digital yang akan digunakan.

3. Use Case Steganografi Diversity, use case ini mendeskripsikan bagaimana pengguna melakukan proses penyisipan dan ekstraksi terhadap citra penampung. Pengguna dapat menekan menu atau tombol yang telah disediakan untuk memulai proses penyisipan maupun ekstraks pesan rahasia dari file citra penampung.

3.4 Pemodelan Dengan Menggunakan Activity
Diagram

Acitivity Diagram merupakan diagram yang memperlihatkan urutan - urutan aktifitas yang dilakukan pengguna selama menggunakan sistem serta proses dan respon sistem yang dilakukan atas interaksi pengguna. Pada tugas akhir ini terdapat dua activity diagram utama, yaitu aktifitas diagram penyisipan dan aktifitas diagram ekstraksi.

\subsection{Activity Diagram Penyisipan}

Activity Diagram penyisipan digunakan untuk memperlihatkan alur aktivitas pengguna dalam menjalankan proses penyisipan pada aplikasi yang dibangun. Aktifitas diagram menggambarkan tentang aktifitas yang terjadi pada sistem. Dari pertama sampai akhir, diagram ini menunjukan langkahlangkah dalam proses-proses kerja sistem yang kita buat di dalam sistem. Adapun langkah-langkah diagram dari Activity Diagram penyisipan dapat dilihat pada gambar 2 dibawah ini.

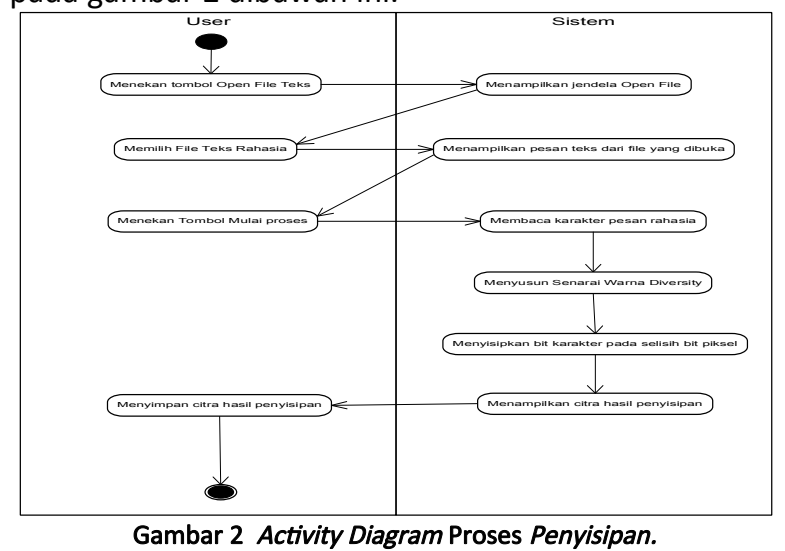

Activity diagram proses penyisipan terlihat pada gambar 2, bahwa pengguna (user) berinteraksi dengan sistem aplikasi. Dimana proses langkah awal pengguna menekan tombol open file teks, sampai ketujuan akhir yaitu menyimpan citra hasil penyisipan data, dimana data yang disisipkan pada selisih bit piksel dapat tersimpan kedalam citra, dengan menyusun senarai warna diversity.

\subsection{Activity Diagram Ekstraksi \\ Activity Diagram ekstraksi digunakan untuk memperlihatkan alur aktivitas pengguna dalam menjalankan proses ektraksi pada aplikasi yang dibangun. Adapaun diagram dari Activity Diagram Ekstraksi dapat dilihat pada gambar 3 dibawah ini.}




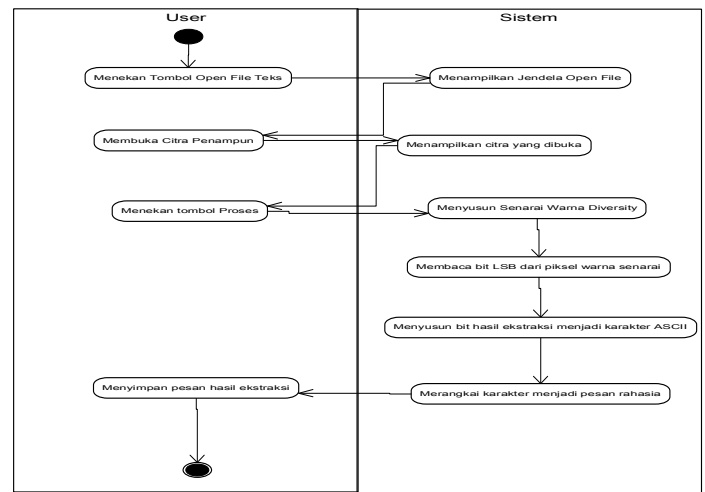

Gambar 3 Activity Diagram Proses Ekstraksi.

Activity diagram proses ekstraksi terlihat pada gambar 3, bahwa pengguna (user) berinteraksi dengan sistem aplikasi. Dimana proses langkah awal pengguna menekan tombol open file teks, sampai ketujuan akhir yaitu menyimpan pesan hasil ekstraksi, dimana ekstraksi dapat menyusun senarai warna diversity dan dapat juga membaca senarai warna piksel yang disisipkan data pada citra digital.

\subsection{Analisis Metode Steganografi Diversity}

Steganografi menggunakan metode algoritma diversity pada konsep nya adalah menyisipkan bit karakter pada senarai warna terpilih yang memiliki jarak warna yang berjauhan. Adapun langkah langkah proses steganografi pada metode diversity adalah sebagai berikut :

1. Menyiapkan citra digital yang akan disisipkan :

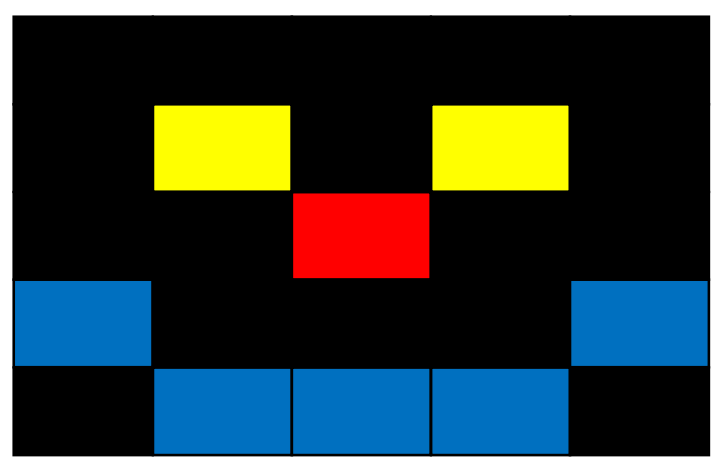

Gambar 4 Citra Digital.

2. Menyiapkan pesan yang akan disembunyikan : UNHAR dan mengkonversi karakter ke dalam bit biner.

$U=01010101, N=01001110, H=01001000, A=$ $01000001, R=01010010$
Deretan bit :

010101010100111001001000010000010101001

3. Menyusun histogram warna dari citra yang digunakan.

Tabel 1 Menyusun Histogram Warna.

\begin{tabular}{|c|l|c|l|}
\hline No & \multicolumn{1}{|c|}{ Warna } & Frekuensi & \multicolumn{1}{|c|}{ Posisi Piksel } \\
\hline 1 & $0,0,0$ (Hitam) & 17 & $\begin{array}{l}\text { P1, P2, P3, P4, } \\
\text { P5, P6, P8, P10, } \\
\text { P11, P12, P14, } \\
\text { P15, P17, P18, } \\
\text { P19, P21, P25 }\end{array}$ \\
\hline 2 & $\begin{array}{l}255,255,0 \\
\text { (Kuning) }\end{array}$ & 2 & P7, P9 \\
\hline 3 & $\begin{array}{l}255,0,0 \\
\text { (Merah) }\end{array}$ & 1 & P13 \\
\hline 4 & $\begin{array}{l}0,0,255 \text { (Biru) } \\
\text { (Miru }\end{array}$ & 5 & $\begin{array}{l}\text { P16, P20, P22, } \\
\text { P23, P24 }\end{array}$ \\
\hline
\end{tabular}

4. Mengambil piksel dengan frekuensi terbesar untuk masuk ke dalam senarai warna awal. Piksel terpilih adalah piksel hitam $(0,0,0)$ dengan frekuensi 17 piksel.

5. Berikutnya adalah menghitung jarak warna terjauh dengan warna acuan yang sudah berada di dalam senarai warna awal.

$D($ Kuning, Hitam $)=\sqrt{(255-0)^{2}+(255-0)^{2}+(0-0)^{2}}=360.62$

$D($ Merah, Hitam $)=\sqrt{(255-0)^{2}+(0-0)^{2}+(0-0)^{2}}=255$

$D($ Biru, Hitam $)=\sqrt{(255-0)^{2}+(255-0)^{2}+(0-0)^{2}}=255$

6. Dari perhitungan jarak diatas diperoleh warna terjauh dari warna senarai awal adalah warna kuning sehingga warna tersebut akan dimasukkan ke dalam senarai warna dimana senarai warna menjadi :

Senarai Warna $=\{$ Hitam, Kuning $\}$

7. Proses dilanjutkan dengan mengulangi langkah 5 namun menggunakan dua acuan warna yaitu hitam dan kuning.

$D($ Merah, Hitam $)=\sqrt{(255-0)^{2}+(0-0)^{2}+(0-0)^{2}}=255$

$D($ Merah, Kuning $)=\sqrt{(255-255)^{2}+(0-255)^{2}+(0-0)^{2}}=255$

$D($ Biru, Hitam $)=\sqrt{(0-0)^{2}+(0-0)^{2}+(255-0)^{2}}=255$ 


\section{$D($ Biru, Kuning $)=\sqrt{(0-255)^{2}+(0-255)^{2}+(255-0)^{2}}=441.67$}

8. Dari perhitungan jarak diatas maka dapat diperoleh Biru adalah warna terjauh dari senarai warna saat ini sehingga Biru akan dimasukkan ke dalam senarai warna.

Senarai Warna $=\{$ Hitam, Kuning, Biru $\}$

9. Dikarenakan warna yang tersisa adalah Merah maka Merah juga akan dimasukkan kedalam senarai warna pada posisi terakhir.

Senarai Warna $=\{$ Hitam, Kuning, Biru, Merah $\}$

10. Proses penyisipan dilakukan pada piksel dari senarai warna yang pertama yaitu senarai warna frekuensi tertinggi adalah warna hitam dan diteruskan pada senarai warna berikutnya yaitu kuning, biru dan merah jika senarai pertama tidak mencukupi.

11. Pada senarai warna diperoleh warna pertama adalah Hitam yang mana terdiri dari 17 buah piksel yang akan digunakan sebagai piksel penampung sebagai berikut.

$P 1=0,0,0=0000$ 0000, 00000000,00000000 disisipkan dengan tiga buah bit berikut awal dari pesan yaitu 010 pada posisi LSB sehingga warna baru dari $\mathrm{P} 1$ adalah :

P1 = 0000 0000, $00000001,00000000=0,1,0$

Deretan bit sisa

1010101001110010010000100000101010010

$\mathrm{P} 2=0,0,0=0000$ 0000, 00000000,00000000

disisipkan dengan tiga buah bit berikutnya dari pesan yaitu 101 pada posisi LSB sehingga warna baru dari P2 adalah :

P2 = $00000001,00000000,00000001=1,0,1$

Deretan bit sisa :

0101001110010010000100000101010010

P3 $=0,0,0=0000 \quad 0000,00000000,00000000$

disisipkan dengan tiga buah bit berikutnya dari pesan yaitu 010 pada posisi LSB sehingga warna baru dari $\mathrm{P} 3$ adalah :

P3 = $00000000,00000001,00000000=0,1,0$

Deretan bit sisa

1001110010010000100000101010010

$\mathrm{P} 4=0,0,0=0000$ 0000, 00000000,00000000

disisipkan dengan tiga buah bit berikutnya dari pesan yaitu 100 pada posisi LSB sehingga warna baru dari P4 adalah :

P4 $=00000001,00000000,00000000=1,0,0$

\section{Deretan bit sisa \\ 1110010010000100000101010010}

$\mathrm{P} 5=0,0,0=0000$ 0000, 0000 0000, 00000000 disisipkan dengan tiga buah bit berikutnya dari pesan yaitu 111 pada posisi LSB sehingga warna baru dari $\mathrm{P5}$ adalah :

P5 = $00000001,00000001,00000001=1,1,1$

Deretan bit sisa : 0010010000100000101010010

P6 = 0,0,0 =0000 0000, 0000 0000, 00000000 disisipkan dengan tiga buah bit berikutnya dari pesan yaitu 001 pada posisi LSB sehingga warna baru dari P6 adalah :

P6 = 0000 0000, $00000000,00000001=0,0,1$

Deretan bit sisa : 0010000100000101010010

$\mathrm{P} 8=0,0,0=0000$ 0000, 00000000,00000000 disisipkan dengan tiga buah bit berikutnya dari pesan yaitu 001 pada posisi LSB sehingga warna baru dari $\mathrm{P} 8$ adalah :

P8 = 0000 0000, $00000000,00000001=0,0,1$

Deretan bit sisa : 0000100000101010010

$\mathrm{P} 10=0,0,0=0000$ 0000, 00000000,00000000 disisipkan dengan tiga buah bit berikutnya dari pesan yaitu 000 pada posisi LSB sehingga warna baru dari $\mathrm{P} 10$ adalah :

$\mathrm{P} 10=00000000,00000000,00000000=0,0,0$

Deretan bit sisa : 0100000101010010

$\mathrm{P} 11=0,0,0=0000$ 0000, 00000000,00000000 disisipkan dengan tiga buah bit berikutnya dari pesan yaitu 010 pada posisi LSB sehingga warna baru dari P11 adalah :

$\mathrm{P} 11=0000$ 0000, $00000001,00000000=0,1,0$

Deretan bit sisa : 0000101010010

$\mathrm{P} 12=0,0,0=0000$ 0000, 00000000,00000000 disisipkan dengan tiga buah bit berikutnya dari pesan yaitu 000 pada posisi LSB sehingga warna baru dari P12 adalah :

$P 12=00000000,00000000,00000000=0,0,0$

Deretan bit sisa : 0101010010

P14 = 0,0,0 = 0000 0000, 00000000,00000000 disisipkan dengan tiga buah bit berikutnya dari pesan yaitu 010 pada posisi LSB sehingga warna baru dari P14 adalah :

P14 = 0000 0000, $00000001,00000000=0,1,0$

Deretan bit sisa : 1010010

$\mathrm{P} 15=0,0,0=0000$ 0000, 00000000,00000000 disisipkan dengan tiga buah bit berikutnya dari 
pesan yaitu 010 pada posisi LSB sehingga warna baru dari P15 adalah :

$\mathrm{P} 15=00000001,00000000,00000001=1,0,1$

Deretan bit sisa : 0010

$\mathrm{P} 17=0,0,0=0000$ 0000, 00000000,00000000 disisipkan dengan tiga buah bit berikutnya dari pesan yaitu 001 pada posisi LSB sehingga warna baru dari P17 adalah :

P17 = 0000 0000, $00000000,00000001=0,0,1$

Deretan bit sisa : 0

P18 = 0,0,0 = 0000 0000, 00000000,00000000 disisipkan dengan tiga buah bit berikutnya dari pesan yaitu 000 pada posisi LSB sehingga warna baru dari P18 adalah :

$\mathrm{P} 18=0000$ 0000, $00000000,00000000=0,0,0$ Deretan bit sisa :

12. Setelah proses penyisipan selesai tahap berikutnya adalah menulis kembali nilai warna hasil penyisipan ke dalam citra yang digunakan sebagai piksel penampung pada senarai warna pertama, yaitu warna hitam yang terdiri dari 17 piksel. Terlihat pada tabel 2.

Tabel 2 Hasil Penyisipan kedalam Citra.

\begin{tabular}{|c|c|c|c|}
\hline No & Pilcsel & $\begin{array}{l}\text { Varna } \\
\text { Lama }\end{array}$ & $\begin{array}{c}\text { Varna } \\
\text { Baru }\end{array}$ \\
\hline 1 & P1 & $\mathrm{O}, \mathrm{O}, \mathrm{O}$ & $0,1,0$ \\
\hline 2 & $\mathrm{P} 2$ & $\mathrm{O}, \mathrm{O}, \mathrm{O}$ & $1,0,1$ \\
\hline 3 & P3 & $\mathrm{O}, \mathrm{O}, \mathrm{O}$ & $0,1,0$ \\
\hline 4 & P4 & $0,0,0$ & $1,0,0$ \\
\hline 5 & PS & $\mathrm{O}, \mathrm{O}, \mathrm{O}$ & $1,1,1$ \\
\hline 6 & P6 & $\mathrm{O}, \mathrm{O}, \mathrm{O}$ & $0,0,1$ \\
\hline 7 & PS & $\mathrm{O}, \mathrm{O}, \mathrm{O}$ & $0,0,1$ \\
\hline 8 & P10 & $\mathrm{O}, \mathrm{O}, \mathrm{O}$ & $\mathrm{O}, \mathrm{O}, \mathrm{O}$ \\
\hline 9 & P11 & $\mathrm{O}, \mathrm{O}=\mathrm{O}$ & $0,1,0$ \\
\hline 10 & P12 & $\mathrm{O}, \mathrm{O}, \mathrm{O}$ & $\mathrm{O}, \mathrm{O}, \mathrm{O}$ \\
\hline 11 & P14 & $\mathrm{O}, \mathrm{O}, \mathrm{O}$ & $0,1,0$ \\
\hline 12 & P15 & $\mathrm{O}, \mathrm{O}, \mathrm{O}$ & $1,0,1$ \\
\hline 13 & P17 & $\mathrm{O}, \mathrm{O}, \mathrm{O}$ & $0,0,1$ \\
\hline 14 & P1 S & $\mathrm{O}, \mathrm{O}, \mathrm{O}$ & $\mathrm{O}, \mathrm{O}, \mathrm{O}$ \\
\hline
\end{tabular}

Hasil penyisipan piksel kedalam citra dari warna lama ke warna baru dari perhitungan warna pertama adalah warna hitam yang terdiri dari 17 piksel sebagai piksel penampung, sehingga dengan menggunakan analisis algoritma di atas maka dapat diambil alur algoritma dan dimasukkan ke dalam flowchart seperti gambar 5 dibawah ini:

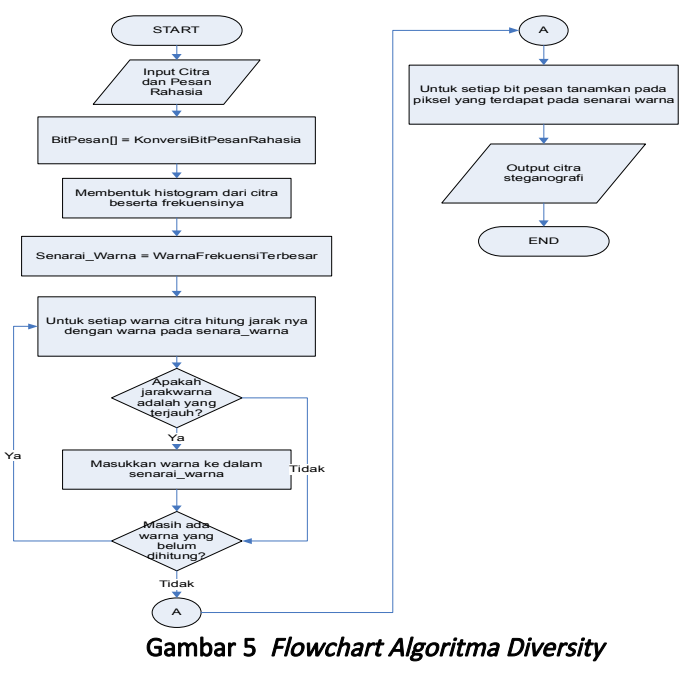

Flowchart algoritma diversity terlihat pada gambar 5, bahwa susunan alur algoritma dari mulai tombol start sampai selesai, yaitu alur proses langkahlangkah hasil penyisipan piksel ke dalam citra dari warna lama ke warna baru sebagai piksel penampung, sehingga menggunakan analisis algoritma dapat diambil alur algoritma dan dimasukan kedalam flowchart tersebut.

\subsection{Perancangan Sistem}

Sistem akan dibangun menggunakan bahasa pemrograman Visual Basic dengan menggunakan software Microsoft Visual Studio 2010. Rancangan antar muka disesuaikan dengan kebutuhan dan software yang digunakan. Antar muka menggunakan 3 form, yaitu terdiri dari form cover, form penyisipan, dan form ekstraksi, seperti tampilan sebagai berikut :

1. Antarmuka Form Cover

Pada form cover terdapat menu utama dimana terdiri dari tiga menu diantaranya menu embed, menu extract dan menu exit, terlihat pada gambar 6 .

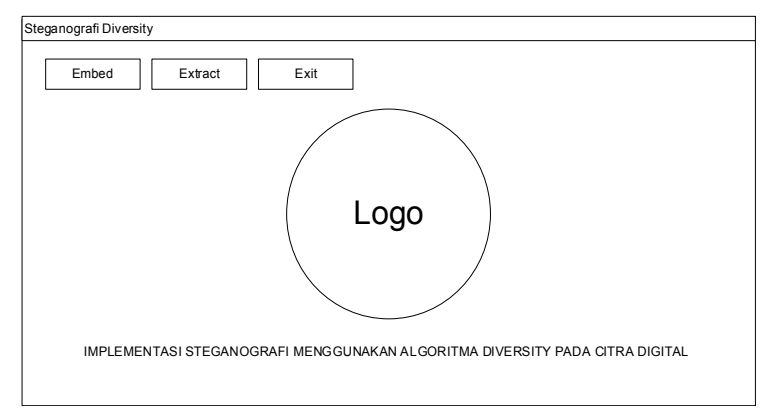

\author{
Program Studi Teknik Informatika \\ Universitas Prima Indonesia (UNPRI) Medan
}




\section{Gambar 6 Rancangan Form Cover.}

Pada gambar 6 komponen yang dipakai untuk membangun antar muka form Cover adalah sebagai berikut :
a. Menu "Embed" : untuk masuk ketampilan Penyisipan.
b. Menu "Extract" : untuk masuk ketampilan Ekstraksi.
c. Menu "Exit" : untuk keluar dari program.

2. Antarmuka Form Penyisipan

Pada form penyisipan terdapat antarmuka yang bertujuan untuk melakukan penyisipan pesan teks menggunakan metode algoritma diversity menggunakan citra tampung yang dipilih oleh pengguna. Proses penyisipan menggunakan jumlah $\mathrm{K}$ bit yang di-input oleh pengguna untuk menentukan bit proses substitusi. Terlihat pada gambar 7 .

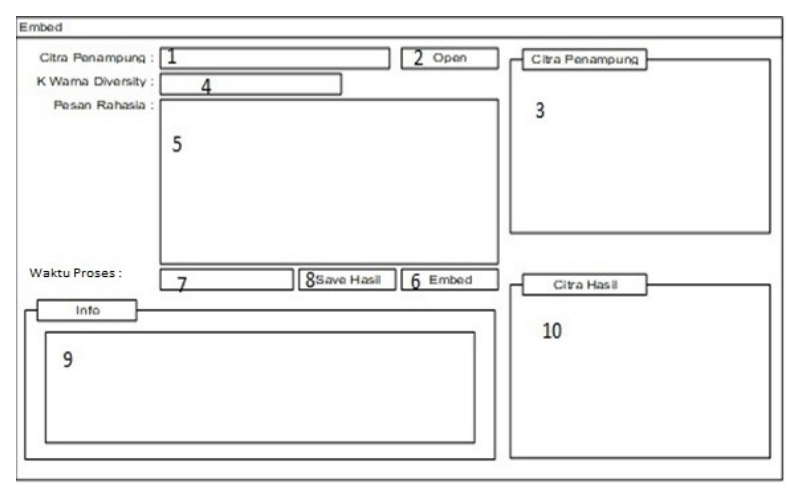

Gambar 7 Rancangan Form Penyisipan.

Pada gambar 7 halaman ini akan digunakan untuk memasukkan pesan rahasia yang diinginkan kedalam citra stegano untuk proses penyisipan pesan rahasia. Pada halaman ini juga pengguna mengetikkan atau menentukan sendiri pesan rahasia yang akan dimasukkan kedalam citra menggunakan algoritma steganografi diversity. Adapun penjelasan dari rancangan form penyisipan yang terlihat dari gambar 7, yaitu:

a. No.1, yang terlihat pada gambar 3.7 dimana akan menampilkan nama dari format citra penampung tersebut.

b. No.2, tombol open, dimana tombol tersebut dikhususkan untuk membuka atau memasukan file citra penampung dengan format .jpg yang ingin kita masukan pesan rahasianya, melalui proses embed.

c. No.3, dimana posisi letak citra penampung yang telah di masukan melalui proses No.2.

d. No.4, dimana pengguna akan memasikan $\mathrm{K}$ warna Diversity sesuai dengan yang dibutuhkan citra penampung, untuk menentukan sebagai nilai jarak atau perbedaan antar piksel.

e. No.5, dikhususkan untuk memasukkan pesan rahasia atau memasukan data teks.

f. No.6, tombol embed adalah tombol penyisipan pesan rahasia kedalam citra penampung.

g. No.7, dimana proses dari embed atau penyisipan data kedalam citra penampung.

h. No.8, tombol save hasil dari proses penyisipan berhasil.

i. No.9, dimana informasi ukuran dari data yang di embed atau di sisipkan kedalam citra penampung.

j. No.10, yaitu citra hasil atau dari citra penyelesaian proses penyisipan data rahasia kedalam citra penampung.

3. Antarmuka Form Ekstraksi

Pada form extract akan digunakan saat melakukan ekstraksi data citra yang rahasia, dimana data yang telah disisipkan oleh proses steganografi dengan metode diversity, terlihat pada gambar 8 .

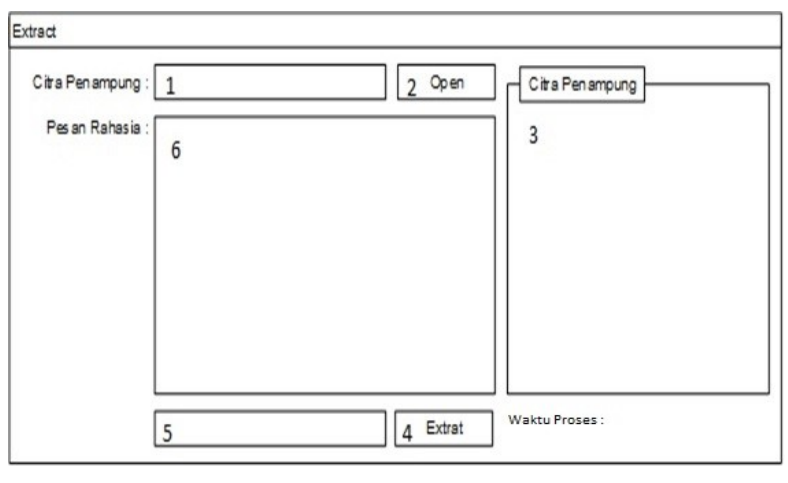

Gambar 8 Rancangan Form Ekstraksi.

Pada gambar 8 halaman ini dikhususkan untuk melakukan proses ekstraksi data pesan rahasia, yang sebelumnya sudah di input ke dalam form penyisipan atau disisip kedalam citra steganografi, data pesan rahasia yang telah disisipkan akan di ekstraksi kedalam 
form ekstraksi tersebut. Adapun penjelasan dari rancangan form ekstraksi yang terlihat dari gambar 8, yaitu:

a. No.1, yang terlihat pada gambar 3.8 dimana akan menampilkan nama dari format citra penampung yang telah melalui proses penyisipan data rahasia.

b. No.2, tombol open, dimana tombol tersebut dikhususkan untuk membuka atau memasukan file citra penampung dengan format .bmp yang sudah disisipkan data melalui proses form penyisipan, yang akan di ekstraksi data pesan rahasianya.

c. No.3, dimana posisi letak citra penampung yang telah di masukan melalui proses No.2

d. No.4, tombol extract dikhususkan untuk melakukan proses ekstraksi data pesan rahasia, yang sebelumnya sudah diinput kedalam form penyisipan.

e. No.5, proses dari extract data rahasia.No.6, tampilan data pesan rahasia yang sudah di ekstraksi.

\section{Implementasi Sistem}

Implementasi sistem merupakan tahap bagaimana sistem untuk dijalankan berdasarkan desain yang telah dibuat dan dirancang pada tahap sebelumnya, kemudian dimasukkan ke bahasa pemograman yang digunakan ke dalam sistem. Implementasi ini menggunakan bahasa pemograman VB.NET.

\subsection{Implementasi Metode Diversity}

Penerapan metode steganografi diversity pada sistem yang dibangun yaitu dalam proses penyisipan data teks pada data citra digital dengan ekstensi .bmp. Pengujian ini akan menggunakan citra dengan bentuk seperti yang terdapat pada gambar 9 .

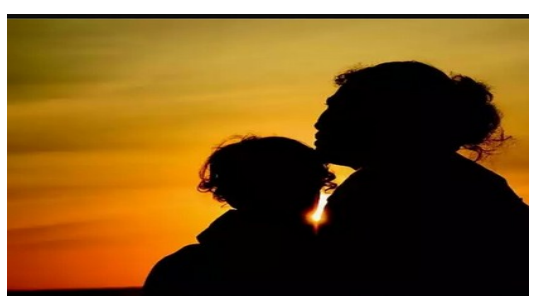

Gambar 9 Citra .bmp Uji Coba.
Pada gambar 4.1 citra digital di atas akan dijadikan sebagai citra penampung yang akan bekerja sebagai penampung informasi rahasia yang akan melewati proses steganografi. Selanjutnya setelah menentukan citra uji atau citra penampung, penulis akan membuka aplikasi steganografi diversity yang telah dibuat. Sebelum hal ini dilakukan penulis akan terlebih dahulu menjabarkan halaman-halaman yang ada beserta dengan fungsi dari masing-masing halaman yang ada pada aplikasi.

\subsection{Antarmuka Sistem}

Pada sistem steganografi menggunakan algoritma diversity yang telah dibuat, terdapat beberapa form yaitu, Form Menu Utama, Form Embed, Form Extract.

\subsection{Form Menu Utama}

Form ini merupakan yang pertama muncul ketika membuka sistem. Pada form ini akan diminta user untuk memilih antara proses embed data, extract data, dan exit, terlihat pada gambar 10.

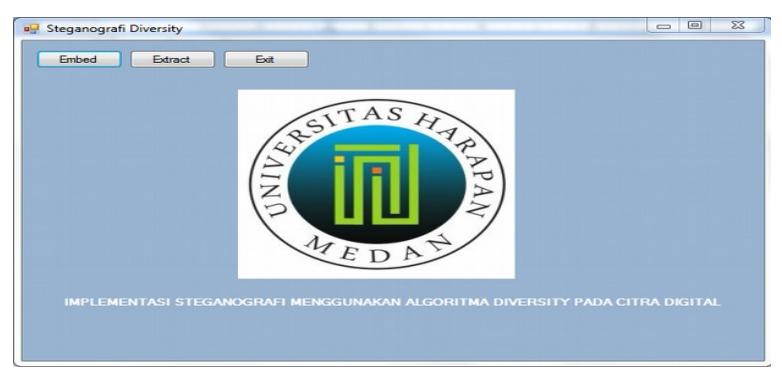

Gambar 10 Form Menu Utama.

Pada gambar 10 form ini merupakan yang pertama muncul ketika membuka sistem. Pada form ini akan diminta user untuk memilih antara proses embed data yang akan sisipkan teks atau pesan rahasia, extract data yaitu untuk membuka pesan rahasia yang telah disisipkan, dan exit adalah tombol keluar dari form utama

\subsection{Form Embed}

Seperti yang terlihat pada gambar 10 yang merupakan form utama. Setelah menekan tombol embed, maka sistem akan menampilkan halaman seperti pada gambar 11 .

\footnotetext{
Program Studi Teknik Informatika

Universitas Prima Indonesia (UNPRI) Medan
} 


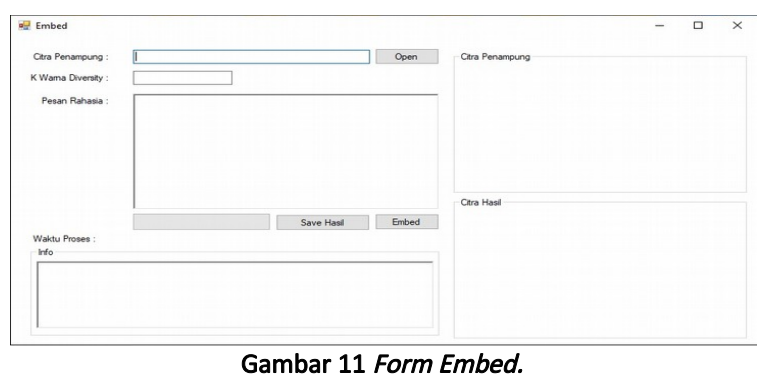

Pada gambar 11 Pada form embed, user diminta untuk memasukan citra uji coba kedalam citra penampung, user juga akan memasukan $\mathrm{K}$ warna diversity dengan jumlah yang diinginkan, untuk pesan rahasia akan dimasukan dan akan dilakukan proses embed yang nantinya hasil embed akan di save terlebih dahulu sebelum di ekstraksi.

\subsection{Form Extract}

Pada form extract ini akan ditampilkan halaman yang dikhususkan untuk proses ekstraksi data dari citra yang sudah melewati proses steganografi, terdapat pada gambar 12 .

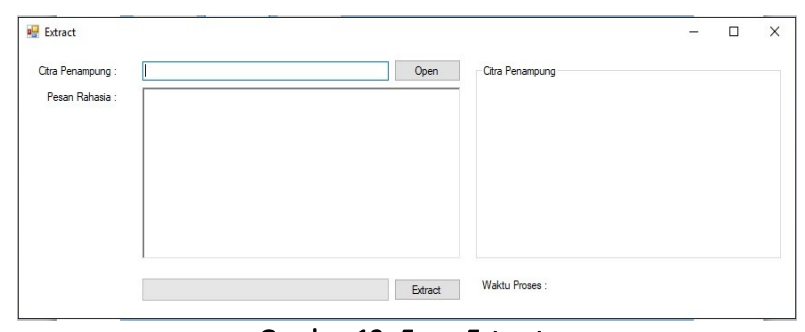

Gambar 12 Form Extract.

Pada gambar 12 Pada form extract, user diminta untuk memasukan citra uji coba yang telah melewati proses stegano atau citra yang telah di embed kedalam citra penampung, user akan melakukan extract data untuk menampilkan pesan rahasia pada citra digital.

\subsection{Pengujian Sistem}

Pengujian sistem dilakukan untuk mengetahui bagaimana jalannya kerja sistem dalam melakukan steganografi data citra digital .bmp atau embed dan kemudian mengembalikannya ke kondisi semula dengan proses extract atau mengambil kembali informasi dari citra digital.

\subsection{Pengujian Embed Pesan Pada Citra Digital}

Pada bagian ini, dimana akan dilakukan pengujian fungsi kompresi dari algoritma yang digunakan dalam sistem. Pengujian dilakukan menggunakan data citra digital dengan proses steganografi pada algoritma diversity, dengan format.jpg yang akan menjadi fotmat .bmp setelah proses dilakukan, dan citra yang akan dimasukan dengan nama lbu dan Anak.jpg dengan besar data 57 KB. Terlihat pada gambar 13.

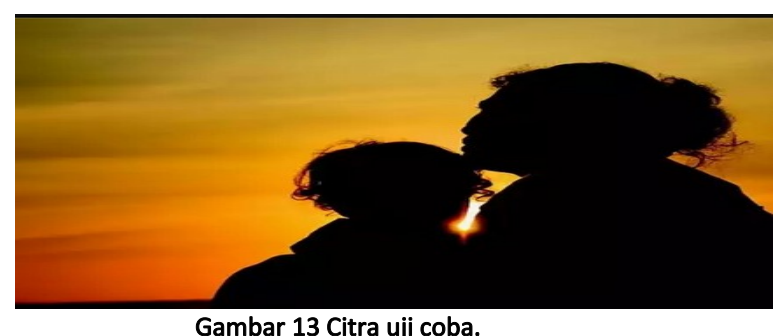

Pada gambar 13 selanjutnya pengguna akan membuka aplikasi dan memilih tombol embed. Setelah menekan tombol embed selanjutnya pengguna akan dipindahkan pada halaman khusus untuk proses steganografi. Berikut tampilan halaman kompresi sistem pada gambar 14 .

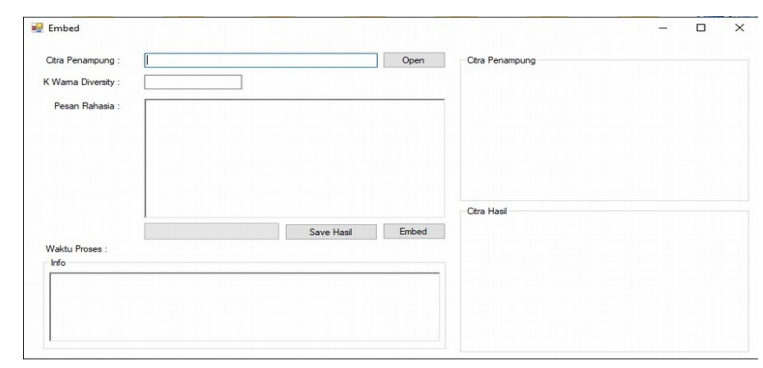

Gambar 14 Halaman Embed.

Pada gambar 14 selanjutnya pengguna akan memasukkan gambar pada sistem. Gambar yang akan dimasukan adalah gambar yang sebelumnya sudah diperkenalkan yaitu Ibu dan Anak.jpg dengan besar data 57 KB. Berikut tampilan sistem pada saat pemilihan data citra digital yang akan diinput kedalam sistem, terlihat pada gambar 15. 


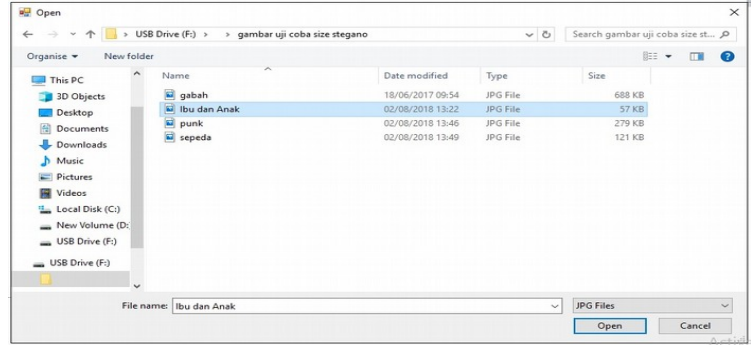

Gambar 15 Pemilihan Citra Digital Untuk Kompresi.

Pada gambar 15 setelah proses memasukan gambar citra digital sudah selesai maka halaman penyisipan kompresi akan menampilkan data pada citra penampung, terlihat pada gambar 16 .

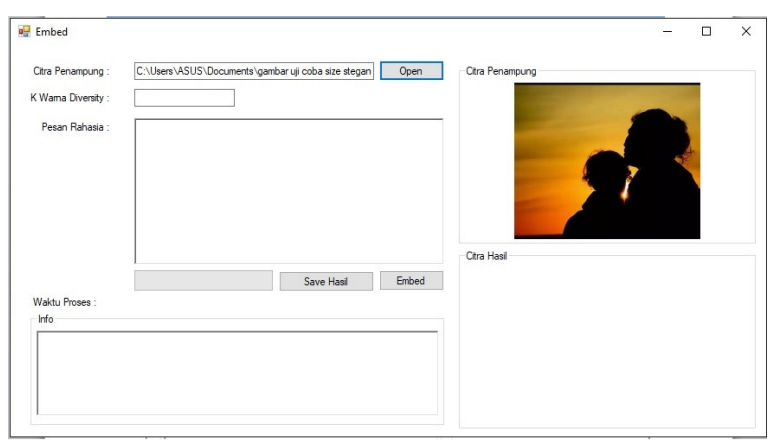

Gambar 16 Input Citra Kedalam Sistem.

Pada gambar 16 setelah data siap di masukan kedalam sistem yaitu citra penampung langkah selanjutnya adalah memasukkan jumlah K warna diversity, sabagai penentu warna diversity, yang kemudian akan dilanjutkan dengan memasukkan pesan rahasia yang ingin di masukkan pada citra. Pada pengujian ini pengguna akan memasukkan pesan sebagai berikut "Ya ALLAH, Saya Sayang Ibu " dengan panjang $\mathrm{K}=12$. Setelah itu, penulis akan menekan tombol "Embed" yang akan menjalankan sistem secara otomatis dan akan menyisipkan data pesan teks pada citra digital yang di pilih, sistem akan menjalankan proses penyisipan kompresi secara otomatis seperti yang tampak pada gambar 17.

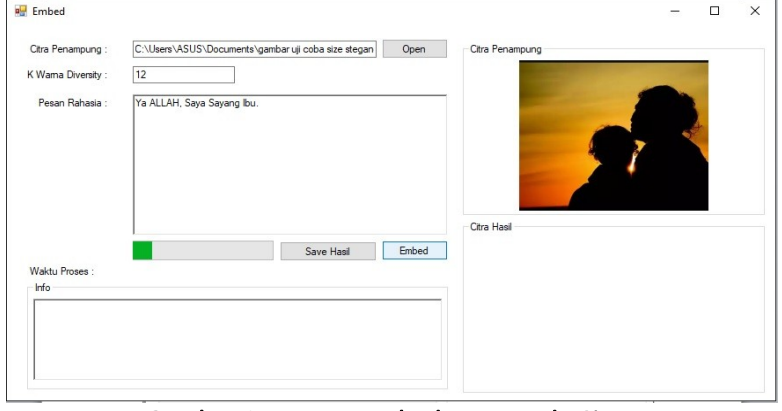

Gambar 17 Proses Embed Pesan Pada Citra.

Pada gambar 17 selama proses kompresi dilakukan, sistem pertama kali akan membaca data piksel dan kemudian memetakannya dan mengubahnya sesuai dengan kamus data dari algoritma. Setelah beberapa waktu, proses embed pun selesai dilaksanakan, hal ini ditandakan dengan munculnya jendela yang menyatakan proses embed berhasil, terlihat pada gambar 18 .

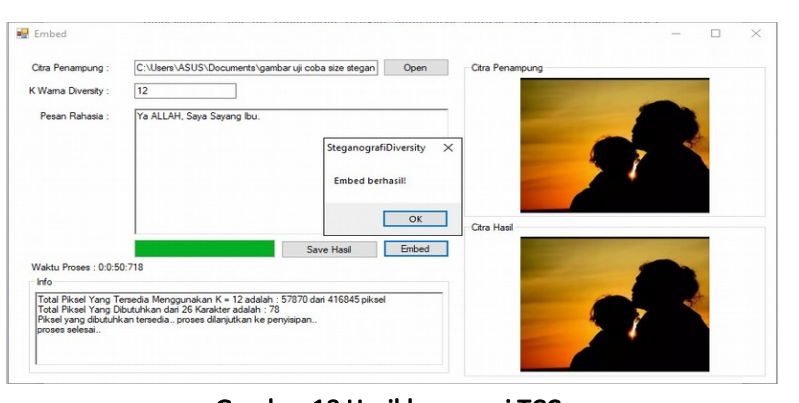

Gambar 18 Hasil kompresi TCC.

Pada gambar 18 setelah proses embed data teks berhasil dilakukan langkah selanjutnya adalah menekan tombol "OK" dan menyimpan citra yang sudah melewati proses steganografi, yang nantinya dilakukan pengujian extract data dari citra stegano. Format file akan berubah menjadi format .bmp, terlihat pada gambar 19.

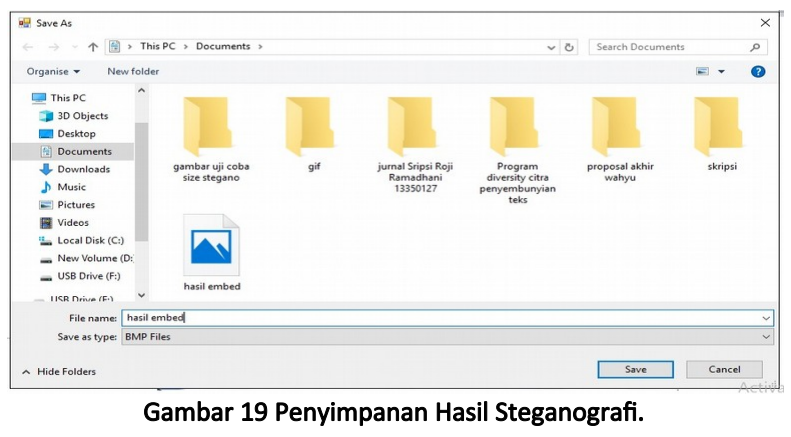


Pada gambar 19 setelah disimpan, file akan mengalami perubahan yang signifikan yang diakibatkan oleh perubahan extensi data dan juga dikarenakan adanya tambahan data pada piksel yang ada didalam citra, terlihat pada gambar 20.

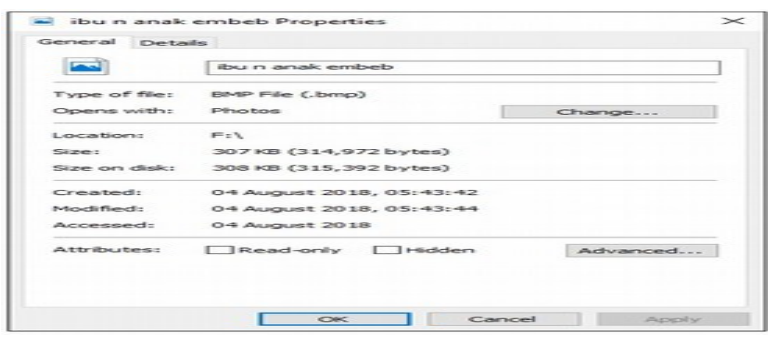

Gambar 20 Data Hasil Steganografi.

Pada gambar 20. selanjutnya memasukan citra dengan menggunakan data citra digital yang sama atau hasil steganografi, pengguna akan melanjutkan pengujian dengan melakukan proses ekstraksi data dari citra steganografi. Proses ekstraksi dapat dilihat seperti yang tampak pada gambar 21 .

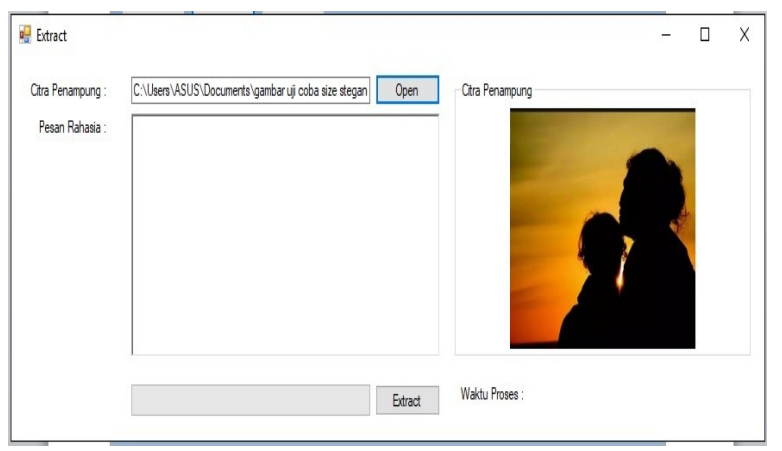

Gambar 21 Ekstraksi Data Dari Citra Stegano.

Pada gambar 21 setelah proses pemilihan gambar stegano selesai, selanjutnya pengguna akan menekan tombol extract yang ada didalam sistem seperti yang tampak pada gambar 22 .

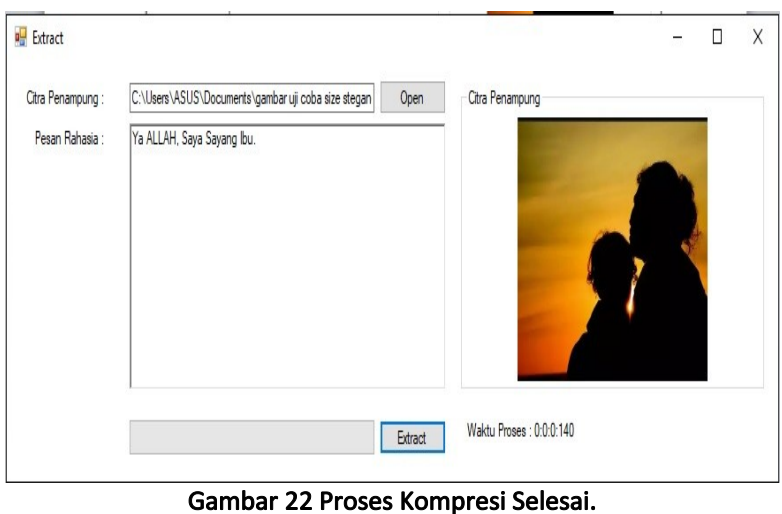

Pada gambar 22 setelah proses extract selesai dapat dilihat bahwa data atau teks rahasia yang sebelumnya kita masukkan kedalam citra dapat di extract dengan baik dan menghasilkan informasi yang sama tanpa mengurangi data asli dari informasi itu sendiri.

Berdasarkan hasil pengujian yang dilakukan oleh penulis dalam proses embed dan extract data pada citra digital, dapat diambil kesimpulan bahwa sistem telah menerima implementasi algoritma diversity dengan baik dan mampu melaksanakan proses steganografi dengan baik dan sesuai dengan algoritma yang diterapkan. Berikut adalah tabel 3 , data hasil size citra awal dan data hasil size citra yang telah di proses steganografi.

\begin{tabular}{|c|c|c|c|c|}
\hline Citra Digital & Size Awal & Size Akhir & $\begin{array}{l}\text { Waktu } \\
\text { Embed }\end{array}$ & $\begin{array}{l}\text { Waktu } \\
\text { Extract }\end{array}$ \\
\hline & $\begin{array}{l}\text { Type: File (.jpg). } \\
\ldots \\
\text { Size: } 57 \mathrm{~KB} \text {. } \\
\text { Size: } 60.0 \mathrm{~KB} \text {. }\end{array}$ & $\begin{array}{l}\text { Type: File (.bmp). } \\
\ldots \\
\text { Size: } 307 \mathrm{~KB} \text {. } \\
\text { Size: } 308 \mathrm{~KB} \text {. }\end{array}$ & $0: 0: 50: 718$ & $0: 0: 0: 140$ \\
\hline & $\begin{array}{l}\text { Type: File (.jpg). } \\
\ldots \\
\text { Size: } 120 \mathrm{~KB} \\
\text { Size: } 124 \mathrm{~KB}\end{array}$ & $\begin{array}{l}\text { Type: File (.bmp). } \\
\ldots \\
\text { Size: } 471 \mathrm{~KB} \\
\text { Size: } 472 \mathrm{~KB}\end{array}$ & $0: 0: 5: 265$ & $0: 0: 0: 132$ \\
\hline PUNK NOT DEAD & $\begin{array}{l}\text { Type: File (.jpg). } \\
\ldots \\
\text { Size: } 278 \mathrm{~KB} \\
\text { Size: } 280 \mathrm{~KB}\end{array}$ & $\begin{array}{l}\text { Type: File (.bmp). } \\
\ldots \\
\text { Size: } 1.37 \mathrm{MB} \\
\text { Size: } 1.37 \mathrm{MB}\end{array}$ & $0: 3: 20: 156$ & $0: 0: 0: 175$ \\
\hline
\end{tabular}

Dari keseluruhan piksel yang dimiliki oleh citra digital, piksel yang digunakan untuk diversity
Program Studi Teknik Informatika

Universitas Prima Indonesia (UNPRI) Medan 
kemungkinan lebih kecil dari total piksel tersebut. Dengan menentukan nilai $\mathrm{K}$ pada sistem algoritma diversity, sistem akan mencari piksel-piksel yang memiliki nilai K tersebut. Namun ukuran citra secara keseluruhan akan berubah pada saat proses steganografi selesai, yaitu size awal dan size setelah steganografi akan menjadi lebih besar.

\section{Kesimpulan}

Berdasarkan penelitian pengembangan aplikasi steganografi dengan menggunakan algoritma Diversity maka dapat diambil beberapa kesimpulan yaitu:

1. Implementasi steganografi menggunakan algoritma Diversity dalam penyembunyian data pada citra digital sudah cukup baik.

2. Dalam merancang program aplikasi pengamanan data pada citra digital menggunakan metode algoritma Diversity sudah cukup baik.

3. Penerapan metode algoritma Diversity dalam aplikasi pengamanan data pada citra digital dengan konsep steganografi sudah cukup baik.

\subsection{Saran}

Saran-saran yang penulis kemukakan diharapkan dapat lebih meningkatkan hasil yang telah didapatkan. Berikut ini beberapa saran yang disampaikan oleh penulis adalah:

1. Diharapkan pada penelitian yang akan datang dapat dilakukan pengujian perbandingan daya tahan dengan metode steganografi lainnya.

2. Media rahasia masih menggunakan teks standart diharapkan dapat dikembangkan menggunakan media lainnya seperti suara, video atau media lainnya.

3. Pada penulisan Tugas Akhir ini hanya menggunakan metode algoritma diversity dalam penyembunyian pesan rahasia, untuk selanjutnya bisa dikembangkan pada metode yang lebih baik.

DAFTAR PUSTAKA

[1] S. E. E. Profile, "Analisa Perbandingan Least Significant Bit Dan End Of File," No. July, 2017.

[2] T. B. Harjo, M. Kapriati, And D. A. Susanto, "Aplikasi Steganografi Menggunakan Lsb ( Least Significant Bit ) Dan Enkripsi Triple Des Menggunakan Bahasa Pemrograman C \#," Sifotek Glob., Vol. 6, No. 1, Pp. 13-17, 2016.

[3] R. Nova And S. Rangkuti, "Analisis Dan
Perancangan Pengamanan Data Pada Citra Digital Dengan Algoritma Least Significant Bit ( Lsb )," Pp. 86-97, 2014.

[4] D. Apriliani And Murinto, "Analisis Perbandingan Teknik Segmentasi Citra Digital Menggunakan Metode Levle-Set Chan \& Vese Dan Lankton," J. Sarj. Tek. Inform., Vol. 1, Pp. 232-240, 2013.

[6] M. Abdul, R. Hi, And W. A. V Files, "Implementasi Mekanisme Keamanan Data Dalam Bentuk Steganografi Dengan Metode Least Significant Bit (Lsb) Pada File Audio Wav," Juristek, Vol. 5, No. 2, Pp. 202-211, 2017. 